\title{
Behavior of Flame Propagation in Biogas Spark Ignited Premix Combustion with Carbon Dioxide Inhibitor
}

\author{
Willyanto Anggono ${ }^{1, a}$, Fandi Dwiputra Suprianto ${ }^{2, b}$, Tubagus P. Wijaya ${ }^{3, c}$, \\ Michael S.C. Tanoto ${ }^{4, d}$ \\ 1,2,3,4 Mechanical Engineering Department, Petra Christian University, Indonesia
}

awilly@petra.ac.id, bfandi@petra.ac.id, 'skyforged@gmail.com, 'dmichael_tanoto@yahoo.com

Keywords: Biogas, Carbon dioxide, Flame propagation, Premix combustion, Sustainable energy.

\begin{abstract}
Biogas is a mixture of gases which commonly consists of methane (up to 50\%) and other inhibitor gases which are dominated by carbon dioxide (up to 50\%). Biogas is produced naturally by the decomposition of organic materials such as vegetation or animal manure in the absence of oxygen and it also contributes less greenhouse gases which may lead to global warming or climate change. The presence of carbon dioxide $\left(\mathrm{CO}_{2}\right)$ in biogas is presumed to have some effects on biogas flame propagation characteristics. This study focuses on the effect of carbon dioxide $\left(\mathrm{CO}_{2}\right)$ as the biggest inhibitor composition in biogas on flame propagation speed as the important flame propagation characteristic in spark ignited premix combustion. Propagating flames are employed to measure the flame propagation speed as a function of the mixture composition. This parameter was measured using a transparent tube fuel chamber with dimensions of $60 \mathrm{~mm}$ inner diameter and 300 $\mathrm{mm}$ height based on DIN 51649 standards and recorded by high speed digital photographic technique. The characteristic of biogas-oxygen flames were studied at stoichiometric, room temperature and atmospheric condition from $0 \%$ to $50 \% \mathrm{CO}_{2}$ biogas inhibitor composition increased by $10 \%$ for each experiment. The results showed that the carbon dioxide decreases flame propagation speed of biogas. These indicated that carbon dioxide reduced reaction rate of biogas premixed combustion.
\end{abstract}

\section{Introduction}

Biogas is a mixture of gases which commonly consists of methane (up to $50 \%$ ) and other inhibitor gases which are dominated by carbon dioxide (up to 50\%). Methane is a flammable gas, whereas, carbon dioxide is inhibitor. Biogas is produced naturally by the decomposition of organic materials such as vegetation or animal manure in the absence of oxygen and it also contributes less greenhouse gases which may lead to global warming or climate change. Biogas, an alternative fuel that is sustainable and renewable which derived from fermentation of organic material in digester [1-4].

Biogas is suitable as an environmentally friendly, alternative fuel to substitute fuels like kerosene, LPG, coal and other materials derived from fossil. Biogas contains many impurities that affect the characteristics of the biogas. While some research has been conducted to study the use of biogas for cooking (stove) and machinery such as gas turbines, more research is required before it becomes a substitute for fossil fuels [1-10].

Inhibitors content of the biogas cause a reduction in the velocity of a laminar burning velocity due to the reduced concentration of methane and reduced flame temperature caused by absorbed heat by carbon dioxide and nitrogen [1-4]. A further research is required to determine the influence of carbon dioxide levels in biogas combustion characteristics. Combustion itself is a chemical reaction between a fuel and oxidizer (oxygen or air) that produce heat and light. The heat or energy that is used to activate fuel molecules is called activation energy. Visual observation towards the produced flame shows that in the absence of carbon dioxide, a perfect combustion produces a blue flame. Additionally, $25 \%$ and $50 \%$ of carbon dioxide content causes a yellowish flame. The color of 
the flame indicates the type of ion produced during combustion process. Flame color is the wavelength of dominant vibrations of ions in flames. $\mathrm{CO}_{2}$ lowers the flame burning velocity due to $\mathrm{CO}_{2}$ molecules inhibits the reaction of collisions between molecules of the hydrocarbon content of propane with molecular oxygen [11].

\section{Experimental Methods}

Details of experimental apparatus are shown in Fig. 1. This study was carried out by using experimental standard a transparent tube fuel chamber with dimensions of $60 \mathrm{~mm}$ inner diameter and $300 \mathrm{~mm}$ height based on DIN 51649 standard and recorded by high speed digital photographic technique.

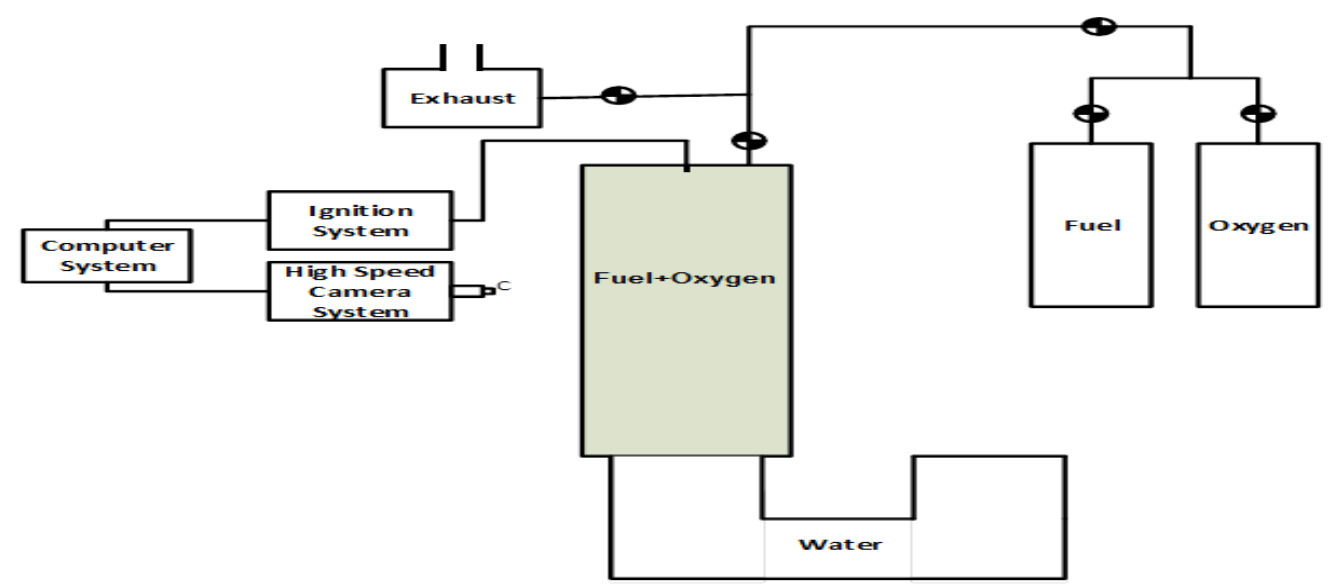

Fig. 1. The Experimental Schematic Diagram

The characteristics of biogas-oxygen flames were studied at stoichiometric, room temperature and atmospheric condition. Initially, all the experiments in this study were implemented at atmospheric pressure $(1 \mathrm{~atm})$ and with inhibitorless biogas at ambient temperatures. The findings were compared with those from biogas (containing $\mathrm{CO}_{2}$ ) at atmospheric pressure with $0 \%$ to $50 \%$ $\mathrm{CO}_{2}$ biogas inhibitor composition increased by $10 \%$ for each experiment.

\section{Results and Discussion}

The characteristics of biogas-oxygen flames were studied at stoichiometric, room temperature and atmospheric condition from $0 \%$ to $50 \% \mathrm{CO}_{2}$ biogas inhibitor composition increased by $10 \%$ for each experiment. The images obtained from the flame propagation within the cylindrical combustion chamber are shown in Fig. 2. 


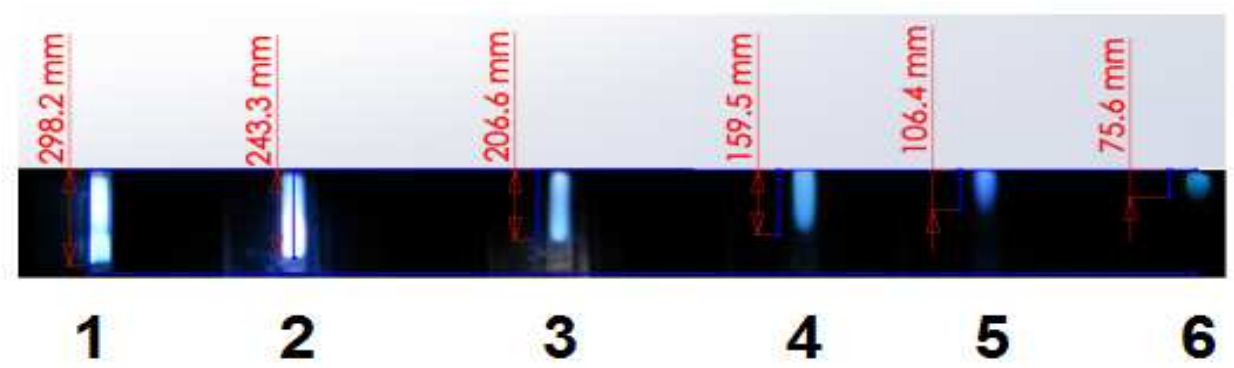

\begin{tabular}{|c|c|c|c|c|}
\hline $\begin{array}{c}\text { Picture } \\
\text { No. }\end{array}$ & $\mathrm{CO}_{2}(\%)$ & $\begin{array}{c}\text { Time } \\
(\mathrm{ms})\end{array}$ & $\begin{array}{c}\text { Distance } \\
(\mathrm{mm})\end{array}$ & $\begin{array}{c}\text { Flame Propagation Speed } \\
(\mathrm{m} / \mathrm{s})\end{array}$ \\
\hline 1 & 0 & 4.17 & 298.2 & 71.5 \\
\hline 2 & 10 & 4.17 & 243.4 & 58.4 \\
\hline 3 & 20 & 4.17 & 214.4 & 49.5 \\
\hline 4 & 30 & 4.17 & 182.2 & 38.3 \\
\hline 5 & 40 & 4.17 & 106.5 & 25.5 \\
\hline 6 & 50 & 4.17 & 75.6 & 18.1 \\
\hline
\end{tabular}

Fig. 2. Flame Propagation Experimental Results

Increasing carbon dioxide concentration in biogas reduces flame propagation speed and the reaction rate was occurred slower. This can be seen with the same time ( 4.17 milliseconds), the distance in which the flame propagates decrease with the increase of carbon dioxide concentrations in the fuel as shown in Fig. 3.

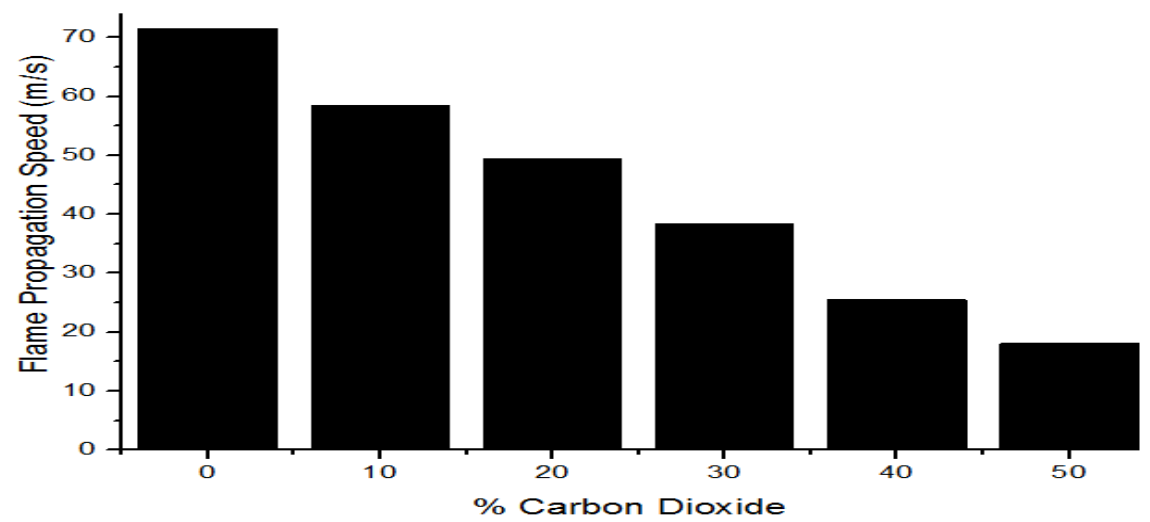

Fig. 3. Effect Carbon Dioxide on Flame Propagation Speed

The decrease of flame propagation speed is seen by the distance traveled by the flame within 4.17 milliseconds. On fuel with $0 \%$ content of carbon dioxide, flame reached the $298.2 \mathrm{~mm}$ in 4.17 ms. On 10\% carbon dioxide inhibotor, the flame reached $243.4 \mathrm{~mm}$ in $4.17 \mathrm{~ms}$, this distance indicates that there is a decrease of flame propagation speed. The same tendency applies to $20 \%$, $30 \%, 40 \%$ and $50 \%$ carbon dioxide inhibotors. $50 \%$ content of carbon dioxide have the slowest flame propagation speed. This is due to the ability $\mathrm{CO}_{2}$ in biogas fuel as an inhibitor that reduces oxidation chemical reactions in combustion. The presence of carbon dioxide reduces the amount of methane in the fuel component so that the total amount of reactive material is lower than that in a pure methane fuel (inhibitorless biogas). Moreover, carbon dioxide will absorb the heat of combustion and hence reduces the combustion temperature.

\section{Conclusion}

The presence of carbon dioxide in biogas reduces flame propagation speed at biogas spark ignited premix combustion. This is due to the ability $\mathrm{CO}_{2}$ in biogas fuel as an inhibitor that reduces oxidation chemical reactions in combustion. The presence of carbon dioxide reduces the amount of 
methane in the fuel component so that the total amount of reactive material is lower than that in a pure methane fuel (inhibitorless biogas). Moreover, carbon dioxide absorbs the heat of combustion and hence reduces the combustion temperature.

\section{Acknowledgments}

Many thanks to Direktorat Jendral Pendidikan Tinggi Kementrian Pendidikan Nasional Republik Indonesia (Hibah Penelitian Fundamental 2014) and Petra Christian University, Indonesia.

\section{References}

[1] Anggono W, Wardana ING, Lawes M, Hughes KJ, Wahyudi S, Hamidi N. Laminar Burning Characteristics of Biogas-Air Mixtures in Spark Ignited Premix Combustion. Journal of Applied Sciences Research 2012;8:4126-32.

[2] Anggono. W., Wardana. I.N.G., Lawes. M., Hughes. K.J., Wahyudi. S., Hamidi. N., and Hayakawa. A.. Laminar Burning Velocity and Flammability Characteristics of Biogas-Air Mixtures in Spark Ignited Premix Combustion. Journal of Physics Conference Series 2013; 423:012015(1-7)

[3] Anggono W, Wardana ING, Lawes M, Hughes KJ, Wahyudi S, Hamidi N. "Laminar Burning Velocity and Flammability Characteristics of Biogas in Spark Ignited Premix Combustion at Reduced Pressure". International Journal Applied Mechanics and Materials 2013;376:79-85.

[4] Anggono W., Wardana ING, Lawes M., Hughes K.J., "Effect of Inhibitors on Biogas Laminar Burning Velocity and Flammability Limits in Spark Ignited Premix Combustion", International Journal of Engineering and Technology 2014;5:4980-87.

[5] Cacua K, Amell A, Cadavid F. Effects of oxygen enriched air on the operation and performance of a diesel-biogas dual fuel engine. Biomass and Bioenergy 2012;45:159-167.

[6] Lichtman R, Ellegard A, Lal S, Sharma N. The Improved Biogas Systems Project: results and future work. Energy for Sustainable Development 1996;3(4):28-42.

[7] Ferrer I, Garfi M, Uggetti E, Marti LF, Calderon A, Velo E. Biogas production in low-cost household digesters at the Peruvian Andes. Biomas and Bioenergy 2011; 35:1688-74.

[8] Bond T, Templeton MR. History and future of domestic biogas plants in the developing world. Energy for Sustainable Development 2011;15(4):347-54.

[9] Lafay Y, Taupin B, Martins G, Cabot G, Renou B, Boukhalfa. Experiment study of biogas combustion using a gas turbine configuration. Experiments in Fluids 2007;43:395-410.

[10] Porpatham E, Ramesh A, Nagalingam B. Investigation on the effect of concentration of methane in biogas when used as a fuel for a spark ignition engine. Fuel 2008;87:1651-9.

[11] Ilminnafik N, Hamidi N, Wardana ING. Behavior of flame propagation in LPG premixed combustion with carbon dioxide inhibitor. International Journal of Academic Research 2011;3(2):705-8. 


\section{Frontiers of Energy, Materials and Information Engineering}

10.4028/www.scientific.net/AMR.1044-1045

\section{Behavior of Flame Propagation in Biogas Spark Ignited Premix Combustion with Carbon Dioxide Inhibitor}

10.4028/www.scientific.net/AMR.1044-1045.251

\section{DOI References}

[3] Anggono W, Wardana ING, Lawes M, Hughes KJ, Wahyudi S, Hamidi N. Laminar Burning Velocity and Flammability Characteristics of Biogas in Spark Ignited Premix Combustion at Reduced Pressure,. International Journal Applied Mechanics and Materials 2013; 376: 79-85. http://dx.doi.org/10.4028/www.scientific.net/AMM.376.79

[5] Cacua K, Amell A, Cadavid F. Effects of oxygen enriched air on the operation and performance of a diesel-biogas dual fuel engine. Biomass and Bioenergy 2012; 45: 159-167. http://dx.doi.org/10.1016/j.biombioe.2012.06.003

[6] Lichtman R, Ellegard A, Lal S, Sharma N. The Improved Biogas Systems Project: results and future work. Energy for Sustainable Development 1996; 3(4): 28-42. http://dx.doi.org/10.1016/S0973-0826(08)60202-1

[7] Ferrer I, Garfi M, Uggetti E, Marti LF, Calderon A, Velo E. Biogas production in low-cost household digesters at the Peruvian Andes. Biomas and Bioenergy 2011; 35: 1688-74. http://dx.doi.org/10.1016/j.biombioe.2010.12.036

[8] Bond T, Templeton MR. History and future of domestic biogas plants in the developing world. Energy for Sustainable Development 2011; 15(4): 347-54.

http://dx.doi.org/10.1016/j.esd.2011.09.003

[9] Lafay Y, Taupin B, Martins G, Cabot G, Renou B, Boukhalfa. Experiment study of biogas combustion using a gas turbine configuration. Experiments in Fluids 2007; 43: 395-410.

http://dx.doi.org/10.1007/s00348-007-0302-6

[10] Porpatham E, Ramesh A, Nagalingam B. Investigation on the effect of concentration of methane in biogas when used as a fuel for a spark ignition engine. Fuel 2008; 87: 1651-9.

http://dx.doi.org/10.1016/j.fuel.2007.08.014 